\title{
B4GALNT1 wt Allele
}

National Cancer Institute

\section{Source}

National Cancer Institute. B4GALNT1 wt Allele. NCI Thesaurus. Code C128483.

Human B4GALNT 1 wild-type allele is located in the vicinity of 12 q13.3 and is approximately $10 \mathrm{~kb}$ in length. This allele, which encodes beta-1,4 Nacetylgalactosaminyltransferase 1 protein, plays a role in the synthesis of glycosphing olipids. Mutation of the gene is associated with autosomal recessive spastic paraplegia 26. 